\title{
DOPING IN SPORT: THE CASE OF FENGING
}

\author{
Maciej Łuczak \\ University School of Physical Education in Poznań \\ Address for coprespondence: \\ Maciej Łuczak \\ University School of Physical Education in Poznań \\ Królowej Jadwigi 27/39, 61-871 Poznań, Poland \\ E-mail: luczak.maciej.awf@wp.pl
}

\begin{abstract}
Ahstract. Most athletes in order to achieve satisfactory results have to train long and hard. However, some of them, aiming at victory at all costs, resort to doping. The benefits of winning are relatively small when compared to the damage of the human organism caused by doping. The phenomenon has been present in cycling, athletics, boxing, football, weightlifting and many other sport disciplines for many years. In fencing only few instances of the use of illegal substances during the competition were revealed, which was reflected in Polish and foreign sports press. In many European countries the use of doping is regulated by the anti-doping rules, regulations and policies that define these practices as penal acts. In Poland the problem of doping was first regulated by the Act on Physical Culture of 1984 and 1996 as well as the he Act of 1985 on Prevention of Drug Abuse. The regulations of FIE fencing competitions, prepared on the request of Polish Fencing Federation on the basis of the FIE competition rules in the disciplinary regulations of competitions prohibited the use of artificial stimulants during or before the competition. The aim of this paper is to present the threats in modern sports with particular attention to the phenomenon of doping in fencing, as well as in social terms. It is a case study and a study of selected issues connected to doping in contemporary sports. The author poses the question whether the fencers often are tempted to support their bodies with doping in order to achieve better results than the representatives of other sports? What percentage of the fencers were using illegal stimulants? Is there is a problem of doping in fencing, and if so, what is its scale?
\end{abstract}

Key worlls: sport, fencing, doping, law

\section{Introduction}

The study outlines the history of doping understood as undesirable, unethical, and illegal uses of performanceenhancing practices and drugs in professional and Olympic sports and in the Olympic movement, with particular consideration of fencing. The study is based on the most recent literature on the subject. The applied research methods include induction, deduction, comparative analysis, and analysis of literature.

The following research questions were posed: What are the current research achievements in the area of sport and, in particular, fencing? How big a problem is doping in fencing compared to other sports? What banned substances have been predominantly used by fencers? What are the training and competitive periods in which the use of illegal substances by athletes intensifies? What sort of substances (soft or hard drugs) have been detected in samples from fencers?, and What are the consequences of the use of performance-enhancing drugs? 
The word doping was first used in the context of sport in 1889 as the name for illicit preparations of drugs and opiates designed to influence (purportedly) the performance of racehorses. ${ }^{1}$ It has entered the general English use in 1935 (Yesalis, Bahrke, 2002).

The word sport originated in Vulgar Latin in the late Roman Empire. Its initial form was disporto, i.e. 'outside the gate' (porta - gate, dis - beyond). In the 18th century sport was defined as a total of all playful competitions. In Poland the term sport was used for the first time in a one-act play Wyścigi konne w Warszawie (Horse races in Warsaw) by Konstanty Gaszyński from 1856 (Lipoński, 2002, pp. 203-204).

Today, sport is understood as "all forms of physical activity, spontaneous or organized, aimed to develop or improve physical and mental fitness, positively affecting the development of social relations or attainment of performance results at all levels" (Badura, Basiński, Kałużny, Wojcieszak, 2011, p. 27).

In competitive sports, doping refers to the use of banned performance-enhancing drugs by athletes, and it is widely used by organizations that regulate sporting competitions. The use of drugs to enhance performance is considered unethical by most international sports organizations, including the International Olympic Committee. The Polish Law on Sport from June 25, 2010 (Art. 43) defines doping as "the presence of a prohibited substance or its metabolites or markers in a sample from a athlete in training or competition". ${ }^{2}$ Doping can be categorized in terms of methods (pharmacological, physiological, gene doping, technology doping) and types (strength, endurance, stimulating) (Sahaj, 2008, pp. 85-91, 2002).

\section{Research on doping in spopt}

Research on doping in sport, including fencing, became prolific at the turn of the 20th and 21st century. Articles on the use of doping in different sports can be found in journals on ethics, law, psychology, medicine, in the sporting press and popular science magazines. There have been, however, relatively few publications on the history of doping in sport. They are mainly German language studies tackling various legal and historical aspects, English language studies on hazards related to the abuse of stimulants.

In 1933 Dr Otto Rieser wrote an article entitled Doping and doping substances. He pointed to the proliferation of performance-enhancing drugs among athletes and blamed physicians for the spread of such practices (Yesalis, Bahrke, 2002). In 1935, the magazine "Zeitschrift Physiologische Chemie" published an article co-authored by K. David, E. Dingemanse, J. Freud, and E. Laqueur on the use of testosterone by athletes (1935, pp. 281-293). More publications on the topic appeared after World War II. Charles E. Yesalis and Michael S. Bahrke (2002) in their article History of doping in sport discussed the most significant cases of use of stimulants and anabolic steroids in the 19th and 20th centuries, and in particular, in the early 21st century by Olympic and professional athletes. A. Singler and G. Treutlein (2012) in their book Doping im Spitzensport. Sportwissenschaftliche Analysen zur nationalen und internationalen Leistungsentwicklung (Doping in competitive sport. Sports and scientific analyses of national and international developments) mentions that anabolic doping was used as early as in the first decade after the foundation of the Federal Republic of Germany. G. Spitzer (2013), in his work Doping in East Germany. A historical outline of secret practices demonstrated the harmful effects of using prohibited substances

\footnotetext{
${ }^{1}$ Most likely to reduce the performance capabilities of a rival horse, i.e. as anti-doping or para-doping.

2 Cf. International Fencing Federation (FIE) Anti-Doping Rules 2015, based on and compliant with the 2015 revised World AntiDoping Code, p. 6; see Klimczyk.
} 
and discussed the role of the VEB Jenapharm company, the manufacturer of a anabolic steroid called turinabol. A monograph by G. Spitzer, E. Eggers, H.J. Schnell, and Y. Wisniewska (2013) Zwyciężyć za wszelką cenę. Doping w Niemczech, historia, prawo, etyka 1972-1990 (To win at all costs. Doping in Germany: history, law, ethics, 1972 1990) reveals the inside story of doping in West Germany in the 1970s and the 1980s. M. Krüger, Ch. Becker, S. Nielsen, M. Reinold (2014) in their book Doping in der DDR: Ein historischer Überblick zu einer konspirativen Praxis. Genese - Verantwortung - Gefahren investigated the development, organizational structure and state policy on doping in East Germany. Before 1960 doping was not a subject of scientific research in West Germany. However, ten years later major doping scandals forced the German sports authorities to tackle the problem. T. Kistner (2015) in The secret history of doping in football described the consequences of using prohibited substances in football. He discussed cases of Italian soccer players in the 1970s and 1980s who died of doping-related causes a few years after completing their sports careers, Algerian Golden Team players and their children born with severe disabilities, and numerous doping scandals in German soccer.

In Poland, R. Dzierżanowski (1980) wrote a brief history of the use of doping substances from ancient times until today in sport and outside sport in Doping by Stanisław Kozłowski and Wojciech J. Rewerski (eds.). Similar issues were discussed by K. Sas-Nowosielski (2002) in Doping nie tylko w sporcie (Doping not only in sport). Another popular science article was published in the „Sport Wyczynowy” (Competitive Sport) magazine (1991, 7-8), titled Próbka nr 0708104, czyli jak w NRD produkowano mistrzów (Sample no. 0708104 or how the DDR manufactured sports champions). It was based on articles from the Stern magazine $(1990,49)$ authored by Teja Fidler and Martin Hägele and concerned state-endorsed doping practices in East Germany (Łuczak 1993, p. 10; Próbka nr..., 1991, p. 130).

\section{Outline histopy of doping in sport}

The use of stimulant drugs in sports can be traced back to ancient times. An old Chinese drawing from c. 3000 BCE shows an emperor chewing a sprig of ma huang (ephedra) containing ephedrine which is known to have stimulating effects. Homer mentioned the use of drugs in The Iliad and The Odyssey (Swaddling, 2004, p. 49). During the games in ancient Thebes in the 6th century BCE, it was prohibited for the participating athletes to consume wine before competition, and priests inspected the breath of all competitors entering the stadium (Rewerski, Nazar, 1995, pp. 17-18).

In 1904, the marathon race at the 1904 Olympics in Saint Louis, which was held in a 30-degree heat, was won by the American runner Thomas Hicks. As Hicks was flagging during the race his assistants gave him doping substances: strychnine, proteins and even brandy, for which he would have been disqualified today (Besala, 2006, p. 47).

One of pioneers of doping research was Alfons Bukowski - a Polish pharmacist from Warsaw who collaborated with the Warsaw Horseracing Society. He tested samples of horse saliva for the presence of alkaloids such as morphine, cocaine, and heroine. He detected doping in racehorses, and his discoveries were reported in an Austrian newspaper "Sportzeitung" in 1912 (278, 280). Soon after, Austrian physicians confirmed Bukowski's test results (Pokrywka, Gorczyca, Jarek, Kwiatkowski, 2013, pp. 68-72). The first official observations of doping use by athletes were made during the 1932 Olympic Games in Los Angeles. Vials with a concoction containing nitroglycerin were found in the quarters of Japanese swimmers, who won a number of Olympic medals (Lis, Olszański, 2000, p. 171). 
During the 1952 Winter Olympics athletes were found to have used amphetamine, and at the Summer Olympic in the same year - testosterone. The 1952 Olympic weightlifting tournament was totally dominated by Soviet athletes who took testosterone before competition. It must be stressed that the Olympic successes of athletes from the so-called Eastern Block countries had an important political dimension, and that the communist state authorities wanted to demonstrate the dominance of their athletes over their counterparts from Western Europe (Pasko).

In Rome, in 1960, a Danish cyclist Knut Enemark Jensen died during a race held in searing heat due to overdosing and, most probably, dehydration. The plague of doping would affect almost all Olympic Games afterwards.

The first French and Belgian anti-doping legislation considering doping as a criminal act from 1965 did not change the situation, due to ineffective enforcement of the law. Only in the period 1960-1967, were more than thirty doping-related lethal cases recorded all over worldwide (Łuczak, 1993, p. 10). ${ }^{3}$

In the late 1960s the use of anabolic steroids became widespread, especially in East Germany. Athletes in the East German state training system were given performance-enhancing drugs (Lis, Olszański, 2000, p. 171), and then their performance was systematically monitored. The supervisor of the state-endorsed project was the Physical Culture Research Institute in Leipzig. A specially designed performance-enhancing drug called "Turibanol" was manufactured in Jena. It was used, for example, by Kristin Otto, a six-time Olympic medalist and seven-time world swimming champion as well as many other athletes (Próbka nr..., 1991, pp. 10-12).

W 1967 the Council of Europe adopted a resolution on anti-doping in sport, and the International Olympic Committee established its own Medical Commission charged with the conduct of the fight against drugs in sport (Smorawiński, Pokrywka, Rynkowski, 2011, pp. 72-83). One year later the first international conference on doping in sport was organized. Mandatory drug tests began to be conducted; however, they were initially inefficient. Different national sports associations also began developing their own anti-doping programs.

One of the most outrageous doping practices was abortion doping used in the 1970s and the 1980s. The practice consisted of inducing pregnancy in female athletes three months before competition. The physiological and hormonal changes in the athlete's body during pregnancy positively affected the athlete's aerobic capacity and muscle strength. The surplus of the red blood cells and a surge in hormone production was used to increase the athlete's performance. Right after a competition the athlete would have an abortion. Good sport results were attained in total disregard of human life (Łuczak, 1992, p. 10).

During the 1976 Olympics in Montreal and the 1988 Olympics in Seoul, in order to avoid detection of illegal substances in Soviet athletes, the USSR authorities provided a special hospital ship, where the athletes were tested for the presence of prohibited substances (Dzierżanowski, Wysoczański, 1995, pp. 35-36). Until 1989 prohibited substances had been detected in three Polish athletes. The first who tested positive was weightlifter Zbigniew Tadeusz Kaczmarek. In 1976, eleven doping cases were revealed (Pasko, pp. 3-4). ${ }^{4}$ However, state-endorsed

3 The German Criminal Code provides for penalties for the use of doping in $\S 263$. However, the execution of this provision is generally put into question. In 1991 there were no legal anti-doping regulations in Germany, and the Independent Doping Commission questioned German national legislation against doping, arguing it would contradict the idea of sport autonomy. In Greece, for example, two legislative acts from July 12, 1975 and September 12, 1986, provide for criminal responsibility for the use of performance-enhancing substances (Szwarc, 1992, pp. 16, 113).

${ }^{4} 2$ from Poland, 2 from Bulgaria, 1 from Romania, 1 from Czechoslovakia, 2 from the USA, and 1 from Sweden. All of them used anabolic steroids. At the 1976 Olympics in Montreal the discus thrower Danuta Zofia Rosani also tested positive for anabolic steroids. 
doping was practiced on a much lower scale in the Polish People's Republic than in East Germany or the USSR (Pasko).

The Los Angeles Olympic Games in 1984 witnessed the use of blood doping (known already in 1947). After the Olympics seven US cyclists (including four Olympic medalists) admitted practicing this method, which had been officially prohibited by the IOC in 1981. The use of erythropoietin (EPO) as a performance-enhancing drug was pioneered in the USA (Chrostowski, 1991, pp. 47-48). Many 1984 Olympic medalists were patients of the notorious endocrinologist Robert Kerr from San Gabriel, California. Kerr prescribed steroids to athletes from twenty countries, including the late sprinter Florence Griffith Joyner, a multiple Olympic medalist from 1984 and 1988 (Internet doping, March 19, 2010).

In Seoul, the Olympic champion in the $100 \mathrm{~m}$ event, Ben Johnson was disqualified for using an anabolic steroid called stanazolol (improving muscle growth). Also seven Bulgarian weightlifters were suspended, including two Olympic champions (Etyka i moralność..., 1991, p. 10; Łuczak, 1993, p. 10).

At the 2006 Winter Olympic Games in Turin the local police and prosecutor's office acting on a tip about organized doping practices, made an overnight raid on the quarters of Austrian biathlonists. Austrian coach Walter Mayer, who had once been suspended for doping violations during the 2002 Winter Olympic Games, fled back to Austria, for which he would be disqualified in 2010. The police found syringes, blood transfusion equipment, and anti-asthma drugs (used illegally to prevent detection of anabolic steroids and EPO). Walter Mayer was interrogated, but no charges were filed.

In the 1990s, Chinese female swimmers trained by coaches from former East Germany who after the fall of the Berlin Wall had immigrated to China, were found to use human growth hormone (HGH) and a number of masking agents. Like their East German counterparts from the 1980s, they trounced their rivals to an extent that the 1996 Olympics were dubbed the Growth Hormone Games (Nosidlak, 2016).

The early 21 st century witnessed a huge scandal in doping involving the cycling star Lance Armstrong, an idol to athletes and fans all over the world. Armstrong won the Tour de France seven times (1999-2005), was a UCI Road World Champion in 1993, and the bronze medalist at the Sydney Olympic Games of 2000. He was subsequently stripped of all his achievements after 1996. Armstrong used blood transfusion banned by the World Anti-Doping Agency (WADA) and other prohibited techniques, for instance, the use of erythropoietin (EPO) (Hamilton, Coyle, 2013, p. 37) - a hormone stimulating the renal function by increasing blood carrying capacity and red cell production, and thus muscle strength and endurance ${ }^{5}$ - steroids, ${ }^{6}$ cortizone, and growth hormone. He probably also used human chorionic gonadotropin (hCG) ${ }^{7}$ (Walsh, 2013, pp. 146, 167, 224). Lance Armstrong collected data on his rivals, and analyzed their reports (Walsh, 2013, p. 152). Michele Ferrari consulted with Chris Carmichael (Armstrong's personal coach) dietary plans, hypoxic training, and the use of altitude tents, i.e. natural means of performance enhancement.

In response to widespread doping practices, in February 1999 the International Olympic Committee in Lausanne organized the World Conference on Doping in Sport attended by representatives of all countries and associations involved in the campaign against illegal doping. The conference adopted the Lausanne Declaration on

\footnotetext{
${ }^{5}$ EPO began to be used in the 1980 s as a stimulating agent by patients with chronic kidney disease and cancer.

${ }^{6}$ Cyclists began to use doping (cocaine, ether, amphetamine) to reduce fatigue and stimulate brain function.

${ }^{7}$ Human chorionic gonadotropin (hCG) is considered a "pregnancy hormone" since its level is elevated during pregnancy.
} 
Doping in Sport, which on February 10, 1999 led to the establishment of the World Anti-Doping Agency (WADA). Soon the World Anti-Doping Code and the Anti-Doping Convention of the Council of Europe were adopted. WADA officially began its activities in 2004, and in the same year it banned the use of gene doping. ${ }^{8}$ In Poland, the first anti-doping lab was opened in the Institute of Sport in Warsaw in September 1987, and one year later the Anti-Doping Sport Commission was established to implement and develop the anti-doping program in Poland (Smorawiński et al., 2011, pp. 72-83). These actions were legally regulated by the Polish Physical Culture Act from July 3, 1984, the Physical Culture Act from January 1996, and the Prevention of Drug Abuse Act from January 31, 1985. The last legislation defined the legal responsibility for taking intoxicants and psychotropic drugs. Regulations of the International Fencing Federation (FIE) from 1962, 1966 and 1978 r. included disciplinary provisions banning the use of artificial stimulants in and out-of-competition. ${ }^{9}$

The list of prohibited doping drugs and methods [in:] Załącznik do zarządzenia Prezesa Urzędu Kultury Fizycznej i Turystyki (Appendix to the Directive of the President of the Physical Culture and Tourism Office from June 20, 1997 (line 432), p. 8, includes substances banned under specific circumstances or in specific sports: A. alcohol, B. marihuana, C. local anesthetics, D. corticosteroids, and E. beta blockers.

In Poland, between 1987 and 1991, 109 positive doping cases were detected in 5200 tested athletes, who included 17 track and field athletes, 55 weightlifters, 5 cyclists, 17 bodybuilders and powerlifters. The majority of drug tests were undertaken out-of-competition (Physical Culture Act, 1984, 1996; Directive of the President of the Physical Culture and Tourism Office from June 1997, approving the list of prohibited drugs and methods; Wysoczański, 1992, p. 83; Dzierżanowski, 1980, pp. 7-39).

\section{Doping in fencing}

Doping cases in fencing have been fairly sporadic (Physical Culture Acts 1984, 1996, Directive 1997). Some fencers were said to take small doses of strong alcohol before important final bouts. Occasionally, fencing coaches recommended to their fencers drinking strong coffee, tea, or beer before tournaments.

The Polish sporting press revealed a number of cases of doping in fencing. During the 1971 World Championships in Vienna all participating fencers underwent drug tests for amphetamine (Jeleń, 1971a, p. 2). The world vice-champion, Michael Maffei, tested positive, however, his case was not resolved. The infuriated editors of the Polish newspaper "Sport" submitted after the scandal a number of anti-doping proposals to the FIE (Jeleń, 1971b, pp. 1, 4).

In 2002 anti-doping rules were violated by Laura Flessel (France), a two-time Olympic champion from 1996, and world epee champion from 1998 and 1999 (Google). Flessel claimed that she had obtained the banned substance from the French team physician, who took responsibility for the violation, and Flassel was disqualified for three months in between competitions. Her suspension expired on December 18, 2002 (Shortnews, 2002). In 2003, Loic Atelly (France) was suspended for 10 months for using nandrolone (an anabolic steroid) and David Boudreault (Canada) for 3 months for taking cannabis (FIE, 2003, p. 4; World Anti-Doping Code, Art. 3). In the 2003/2004 season only one case of doping was detected in Caitlin Thompson (USA) who used I-methamphetamine. She received an

${ }^{8}$ Gene therapy is aimed at correcting or supplementing damaged genes responsible for development of diseases. It consists of therapeutic delivery of correct genes into the genetic structure of specific cells (Chrostwoski, 2005, p. 91).

9 The Prevention of Drug Abuse Act from January 31, 1985 stipulates that doping practices can be penalized, if they are related to the use of "intoxicants", "psychotropic drugs" and "preparations" (Szwarc, 1992, p. 121). 
official warning and was stripped of all points scored in the competitions in which she was tested positive (FIE, 2004, p. 6). In the $2004 / 2005$ season hydrochlorothiazide (medication used to treat high blood pressure) was detected in samples from Jung Hwan Kim (South Korea). The FIE then suspended him for a year (FIE, 2005, p. 6).

On August 1, 2008, a 22-year-old top Italian foil fencer Andrea Baldini was tested positive for banned substances after a team tournament in Kiev won by Italy against Poland 45-30. According to FIE Anti-Doping Rules (1.11) "If a member of a team is found to have committed a violation of these Anti-Doping Rules during an event in which he fenced, the team shall be disqualified from the event with all of the resulting consequences including forfeiture of any medals, points and prizes and the other teams ranked after the team disqualified move up one place in the results of the competition". This disqualification meant that the tournament champion title went to the Polish team. As reported by the Polish newspaper "Rzeczpospolita": "The Italian Fencing Association commenced its investigation (...) Badini tested negative twice by the end of June. The use of doping after the Olympic qualifications would have been pointless. After the scandal, Baldini stated that he felt wronged by not qualifying for the Olympics. The investigation revealed that a third party was accountable for providing Baldini with the prohibited substance. It was considered a mitigating circumstance" (Sportowe Fakty WP, 2009). In 2008 he was a third athlete caught using performance-enhancing substances after Fracesco Ricco in the Tour de France, and UCl World Road Champion, Marta Bastianelli (mat-fencing.com, 2016).

In 2009 a 20-year-old Polish foil fencer Michał Majewski tested positive for cocaine after the World Cup in Espinho, Portugal. The FIE Disciplinary Tribunal in its ruling from May 24, 2009 disqualified Majewski for two years (Wikipedia; FIE).

Fifty violations of anti-doping rules were recorded in 2013. A comparison of data from Poland and other countries shows that this number is disturbingly high. Also athletes have been shown to reach for stimulants present in dietary supplements less often than for anabolic androgenic steroids, i.e. for "hard" doping. If they had realized the hazards of using these substances, they may have probably given them up (Smorawiński, 2013, p. 1).

A two-year ban (January 23, 2013 - January 22, 2015) was received by the Russian fencer Yann Pishchikov for using stanozolol and methylhexaneamine during a men's epee satellite tournament in Antalya, Turkey in November 2012. Nasr Alsaadi (Qatar) was also suspended for two years (May 8, 2014 - July 7, 2016), after testing positive for Clenbuterol during out-of-competition anti-doping control (FIE, 2014).

According to a WADA report, 305,888 samples were taken from athletes from all over the world in 2014, including 22,584 samples as part of the athlete biological passport testing program. Prohibited substances were detected in 3,153 cases. As far as particular sports were concerned, the highest number of positive samples were found in weightlifters ( 169 positive samples out of $8,806-1.9 \%$ ), boxers ( 55 out of $4,258-1.3 \%$ ), wrestlers (60 out of $5,15-1.2 \%$ ), taekwondo practitioners (22 out of $2,034-1.1 \%$ ), track and field athletes (261 out of $25,830-1 \%$ ), cyclists (221 out of $22,471-1 \%$ ), judoists (40 out of $4,453-0.9 \%$ ), sport shooters ( 23 out of $2,616-0.9 \%$ ), rugby players (57 out of $6,961-0.8 \%$ ), basketball players -37 out of $5,439-0.7 \%$ ), soccer players (144 out of $31,242-$ $0.5 \%$ ), and fencers (4 out of $1,609-0.2 \%$ ) (FIE, 2003).

According to fencing coaches, doping cases in fencing are sporadically detected every few years. It might be assumed that fencers performing intense exercises in the precompetitive training period may be occasionally tempted to use anabolic steroids, e.g. testosterone. They might also be tempted to use beta2-adrenergic agonists as they cause dilation of bronchial passages and improve pulmonary ventilation and exercise performance (endurance) (WADA, 2014). 
The low number of detected cases of the use of banned substances in fencing may indicate that the problem of doping in fencing is negligible.

\section{Conclusion}

Stimulating substances have been known since ancient times. They became used on a greater scale in the 1970s and the 1980s. Doping is used in a variety of sports. Data from anti-doping studies show that performanceenhancing drugs are most often taken by strength athletes (weightlifters), combat athletes (boxers, wrestlers, taekwondo practitioners, judoists) and cyclists. In comparison, doping cases in fencing have been negligible. Fencers have predominantly used less harmful substances, although they also occasionally resorted to anabolic steroids. The scale of drug use in sport is curbed by anti-doping tests; however, the desire to win often outweighs the common sense.

\section{References}

American Anti-Doping Agency (USADA). Union Cycliste International (UCI) Międzynarodowa Unia Kolarska. https://www.wada-ama. org/ https://www.wada-ama.org (access on 5.03.2016).

Badura, M., Basiński, H., Kałużny, G., Wojcieszak, M. (2011). Ustawa o sporcie. Komentarz. Warszawa: Lex a Wolters Kluwer business. Besala, J. (2006). Na dopingu. Fokus, 5, 47.

Chrostowski, K. (1991). Środki i metody dopingu. Sport Wyczynowy, 7-8, 47-48.

Chrostwoski, K. (2005). Doping genowy - nowe zagrożenie dla sportu, Sport Wyczynowy, 9-10, 91.

David, K., Dingemanse, E., Freud, J., Laqueur, E. (1935). Über Krystallinsches Männliches Hormon aus Hoden (Testosteron) 69 History of Doping in Sport Wirksamer als aus Harn oder aus Cholesterin Bereitetes Androsteron [Crystalline male hormone from testes (testosterone) more active than androsterone preparations from urine or cholesterol]. Zeitschrift Physiologische Chemie, 233, 281-293.

Dzierżanowski, R. (1980). Historia dopingu farmakologicznego. In: S. Kozłowski, W.J. Rewerski (eds.), Doping (pp. 7-39). Warszawa. PZWL.

Dzierżanowski, R., Wysoczański, R. (1995), Historia dopingu farmakologicznego. In: W. Rewerski, K. Nazar (eds.), Doping (pp. 35-36). Warszawa: PZWL.

Etyka i moralność w sporcie (1991). Sport Wyczynowy, 7-8, 10.

FIE (2003). Annual Report of the Executive Committee.

FIE (2004). Annual Report of the Executive Committee.

FIE (2005). Annual Report of the Executive Committee.

FIE (2014). Anti-Doping Rule Violations. Retrieved from: http://static5.fie.org/uploads/5/29094-anti-doping\%20rule\%20violations-807-2014.pdf.

FIE. Biografia Michała Majewskiego. Retrieved from: http://fie.org/fencers/biographies.

Hamilton, T., Coyle, D. (2013). Wyścig tajemnic. Kraków: SQN.

http://www.liberation.fr/sports/2002/11/04/laura-flessel-suspendue-et-revoltee_420549 (access: 5.03.2016).

https://translate.google.pl/translate?hl=pl\&sl=en\&u=http://fie.org/uploads/4/21351-RM-03-ANG.pdf\&prev=search (access on 5.03.2016). International Fencing Federation (FIE) Anti-Doping Rules 2015, Based on and compliant with the 2015 revised World Anti-Doping Code. Internet doping, 19.03.2010.

Internetowy Magazyn Szermierczy mat-fencing.com (2016). Andrea Baldini na dopingu! Retrieved from: http://www.mat-fencing.com/ page. php?id=33.

Jeleń, J. (1971a). Wiedeński precedens. Sport, 109, 2.

Jeleń, J. (1971b). Złowrogi cień na federacji FIE. Sport, 112, 3-4.

Kistner, T. (2015). Schuss: Die geheime Dopinggeschichte des Fußballs. Monachium: Droemer. 
Klimczyk, A. Doping w sporcie - prawne aspekty. Retrieved from: http://journal.rsw.edu.pl/index.php/JHS/article/view/2014\%3B4\%28 14\%29\%3A285-293/1864.

Kozłowski, S., Rewerski, W.J. (ed.) (1975, 1980). Doping, Warszawa: PZWL.

Krüger, M., Becker, Ch., Nielsen, S., Reinold, M. (2014). Doping und Anti-Doping in der Bundesrepublik Deutschland 1950 bis 2007 Genese - Strukturen - Politik. Hildesheim: Arete Verlag.

Lipoński, W. (2002). Sport. In: S. Sierpowski (ed.), Polska na tle procesów rozwojowych Europy w XX wieku (pp. 203-204). Poznań: Instytut Historii UAM.

Lis, J., Olszański, T. (2000). Od Aten do Sydney. Warszawa: Polskie Wydawnictwo Sprint.

Łuczak, M. (1992). Doping w sporcie (II). Przegląd Koniński, 51, 10.

Łuczak, M. (1993). Doping w sporcie (III, IV). Przegląd Koniński, 1, 10.

Nosidlak, T. (2016). Krótka historia dopingu w sporcie. Retrieved from: http://akademia.kfd.pl/publikacje/krotka-historia-dopingu-wsporcie.html.

Pasko, A., Doping w sporcie PRL jako problem polityczny (maszynopis).

Pokrywka, A., Gorczyca, D., Jarek, A., Kwiatkowski, D. (2013). Alfons Bukowski. Polski farmaceuta, pionier badań antydopingowych (1858-1921). Analityka: nauka i praktyka, 1, 68-72.

Próbka nr 0708104, czyli jak w NRD produkowano mistrzów. (1991). Sport Wyczynowy, 7-8.

Rewerski, W., Nazar, K. (1995). Doping. Warszawa: PZWL.

Sahaj, T. (2002). Doping - koń trojański współczesnego sportu. Sport Wyczynowy, 1-2, 81-89.

Sahaj, T. (2008). Czy to jest technodoping? Sport Wyczynowy, 44-6, 85-91.

Sas-Nowosielski, K. (2002). Doping nie tylko w sporcie, Katowice: Akademia Wychowania Fizycznego w Katowicach.

Shortnews (2002). Milde Strafe wegen Doping gegen Fechterin Laura. Retrieved from: Flesselhttp://www.shortnews.de/id/421325/ milde-strafe-wegen-doping-gegen-fechterin-laura-flessel „Frankfurter Algemeinezeitung” 2002 (16.08.2002).

Singler, A., Treutlein, G. (2012). Doping im Spitzensport. Sportwissenschaftliche Analysen zur nationalen und internationalen Leistungsentwicklung. Verlag: Meyer \& Meyer Fachverlag.

Smorawiński, J. (2013). Wiadomości od przewodniczącego Komisji. In: Antydoping. Raport roczny. Warszawa: Komisja do Zwalczania Dopingu w Sporcie.

Smorawiński, J., Pokrywka, A., Rynkowski, M. (2011). Wybrane zagadnienia zarządzania systemem antydopingowym w Polsce i na świecie. Zeszyty Naukowe, 197, 72-83. Poznań: Uniwersytet Ekonomiczny.

Spitzer, G. (2013). Doping in der DDR: Ein historischer Überblick zu einer konspirativen Praxis. Genese - Verantwortung - Gefahren (Reihe: Doping, Enhancement, Prävention in Sport, Freizeit und Beruf 8), Köln. Sportverlag Strauss.

Spitzer, G., Eggers, E., Schnell, H.J., Wisniewska, Y. (2013). Siegen um jeden Preis. Doping in Deutschland: Geschichte, Recht, Ethik 1972-1990. Göttingen: Verlag Die Werkstatt.

Sportowe Fakty WP (2009). Baldini skazany za doping ale wraca na plansze. Retrieved from: http://sportowefakty.wp.pl/inne/70038/ baldini-skazany-za-doping-ale-wraca-na-plansze.

Swaddling, J. (2004). Starożytne igrzyska olimpijskie. Poznań: Axis.

Światowy Kodeks Antydopingowy, 1.01.2009.

Szwarc, A.J. (1992). Doping i prawo. Przedmowa, In: A.J. Szwarc (ed.), Prawne problemy dopingu w sporcie (pp. 13-19). Poznań: Polskie Towarzystwo Prawa Sportowego.

Szwarc, A.J., (1992). Doping w sporcie i odpowiedzialność karna. In: A.J. Szwarc (ed.), Prawne problemy dopingu w sporcie (pp. $93-$ 120). Poznań: Polskie Towarzystwo Prawa Sportowego.

Szwarc, A.J., Doping w sporcie i odpowiedzialność karna, In: A.J. Szwarc (ed.), Prawne problemy dopingu w sporcie (pp. 93-120). Poznań: Polskie Towarzystwo Prawa Sportowego.

Ustawa z dnia 25 czerwca 2010 r. o sporcie (Dz.U. 2014, poz. 715).

Ustawa z dnia 3 lipca 1984 r. o kulturze fizycznej (Dz.U. 1984, nr 34, poz. 181).

Ustawa z dnia 31 stycznia 1985 r. o zapobieganiu narkomanii (Dz.U. 1985, nr 4, poz. 15 ze zm.).

Ustawa z dnia18 stycznia 1996 r. o kulturze fizycznej (Dz.U. 1996, nr 25, poz. 113). 
WADA (2014). Światowy kodeks antydopingowy. Lista zabroniona 2015. Retrieved from: http://www.plk.pl/internalfiles/fckfiles/file/ dokumenty/regulaminy2015/Lista\%20zabroniona\%20WADA\%202015_pl.pdf.

Walsh, D. (2013). Oszustwo niedoskonałe. Jak zdemaskowałem Lance'a Armstronga. Kraków: Znak.

Wikipedia (a). Doping wydolnościowy. Retrieved from: https://pl.wikipedia.org/wiki/Doping_wydolno\%C5\%9Bciowy.

Wikipedia (b). Michał Majewski (szermierz). Retrieved from: https://pl.wikipedia.org/wiki/Micha\%C5\%82_Majewski_(szermierz).

Wysoczański, R. Realizacja Konwencji Antydopingowej Rady Europy i Międzynarodowej Karty Olimpijskiej przeciwko Dopingowi w Sporcie w polskich regulaminach sportowych oraz w działalności edukacyjnej i represyjnej. In: A.J. Szwarc (ed.), Prawne problemy dopingu w sporcie (pp. 79-84). Poznań: Polskie Towarzystwo Prawa Sportowego.

Yesalis, Ch.E., Bahrke, M.S. (2002). History of Doping in Sport. International Sports Studies, 24 (1), $42-76$.

Zarządzenie Prezesa Urzędu Kultury Fizycznej i Turystyki z dnia 20 czerwca 1997 r. w sprawie zatwierdzenia listy zabronionych środków farmakologicznych i metod uznanych za dopingowe.

Cite this article aS: Łuczak, M. (2016). Doping in Sport: The Case of Fencing. Central European Journal of Sport Sciences and Medicine, 13 (1), 133-142. DOI: 10.18276/cej.2016.1-14. 